Public Abstract

First Name:Ramsay

Middle Name:Bishop

Last Name:Wise

Adviser's First Name:Andrew

Adviser's Last Name:Hoberek

Co-Adviser's First Name:

Co-Adviser's Last Name:

Graduation Term:FS 2012

Department:English

Degree:PhD

\title{
Title:FILM IN POST-WORLD WAR II AMERICAN FICTION
}

This dissertation is an exercise in intertextual analysis and an effort toward historicizing film referentiality in American fiction. It focuses on four novels, Walker Percy's The Moviegoer, Thomas Pynchon's Gravity's Rainbow, Jessica Hagedorn's Dogeaters, and Han Ong's Fixer Chao, and includes an epilogue on Don DeLillo's Underworld. As a means of offering an alternative to exhausted and limiting categories such as Modernist and postmodernism, I map these novels onto a cinematic, rather than literary, timeline. My argument is that close-reading the film references and filmic form of these novels informs not only our understanding of them as individual texts, but offers an alternative means by which to situate them historically.

To this end, I discuss the first two novels in part against the backdrop of the film era in which they were written: the transition of Old to New Hollywood in early 1960s for The Moviegoer, and the rise of New Hollywood, the American New Wave, and the American auteur in the 1970s for Gravity's Rainbow. For Dogeaters, I examine Hagedorn's use of the historical timeline and critical trajectory of melodrama from the 1950 s through the early 1980 s as a means of establishing narrative continuity. For Fixer Chao I address cinema's association with the concept of the American Dream through films from the Old Hollywood era through contemporary blockbusters and, ironically, canonized Japanese filmmakers.

This dissertation is intended as an alternative approach to understanding and situating these novels among twentieth century American literature. 